\title{
ISSURES OF TEXTILE EXPORTERS IN THE CONTEXT OF PAK-INDIA TRADE
}

\author{
Faiz Muhammad Shaikh \\ Assistant Professor \\ SZABAC-Dokri-Larkana-Sindh \\ Pakistan \\ faizanmy2000@hotmail.com \\ Dr.Anwar Ali Shah G.Syed \\ Pro-Vice Chancellor \\ Sindh University Campus Dadu \\ faizanmy2000@hotmail.com \\ Zahid Hussain kazi \\ Assistant Professor \\ IBA-University of Sindh jamshoro
}

\begin{abstract}
This research investigates the issues of Textile exporters in the context of PAK-India trade relation. Data were collected from 100 exporters by using simple random technique. Data were analyzed by using SPSS-20 version, A structural questionnaire was developed for the reliability and validity of the data. It was revealed that that respondents regard governmental regulations, customs procedure and licensing, technical standards and health regulations, sanitary and phytosanitary measures and certification as the major barriers to export. The anti-dumping and tariff barrier are not the major barriers but tends to be the major ones. The tariff barrier may be low due to several rounds of GATT and WTo. It was further revealed that the respondents regard the market access problems and labeling and packaging as the major barriers to export. Although not the major barriers but cultural one, the currency exchange rate and informational barrier tend to be the major barriers to export. The Legal and Political barriers, Languages and Customs, demand of the product, working structure / schedule of the targeting country, business environment are not regarded as barriers to export.
\end{abstract}

Key Words-ISSUES, PAK-INDIA, TRADE.

\section{Council for Innovative Research}

Peer Review Research Publishing System

\section{Journal: International Journal Of Management \& Information Technology}

Vol. 10, No 5

editorsijmit@gmail.com

www.ijmit.com 


\section{Introduction:}

Textile industry of Pakistan is broadly divided into many sectors that are Ginning, Spinning, Weaving, Knitting, Towel, Dying, Printing, Processing, Hosiery, Made-ups and Garments. As the first objective is concerned with understanding the current status of textile industry; in this connection a survey of the entire textile industry will be conducted. A total of 48 companies were be selected for conducting the research in Hyderabad, Kotri, Karachi, Faisalabad and Lahore region including the key integrated textile units to ensure full representation of all sectors. Further the above sectors of textile industry were lumped together into four major sectors as Spinning, Weaving (including Knitting, Dying \& Printing (including Processing and Bleaching), and Garments (including Made-ups, towel, Hosiery and other manufactured items) for compiling the qualitative information.. Therefore the starting 14 years from 1980 to 1994 are considered as the time period with quotas, whereas the last 14 years from 1995 to 2009 are considered as the quota free era. In the third objective developing countries like China, India, Srilanka and Bangladesh are taken into account to analyze the effects of WTO on them. Here the information collected through the above mentioned secondary sources regarding the benefits of becoming the member of WTO and the problems associated with its implementation are highlighted.

\section{The Textile Industry of Pakistan}

One of the major economic indicators for the development of Pakistan economy is textile Industry. Textile Industry is an important source of the overall and major export of the country. In fact, Pakistan is ranked in top most leading cotton producing countries of the world. Statistically, till 1997 Pakistan was named as world's largest exporter of yarn. In 1999, it was ranked on the second position in the largest exporter of textile made-ups list. In textile made-ups sources, the second largest sources were the bed wear and linens sub sectors. These both shared about 28 per cent share of total textile made-ups in 1999 (SMEDA, 2002). In addition, Pakistan became second largest exporter of bed wear and linen globally during that period.

Further statistics shows that during the period of 1999-00 Pakistan had about 443 textile units, 8,477,000 spindles, 149,780 rotors and 9944 looms. Then a satisfactorily increase was found in all these elements from 2000-06 as the textile units increased to 461 , spindles to $10,437,000$, rotors to 155,104 and looms to 8747 . Furthermore, in 2006-07 there were 567 units, 1198000 spindles, 11,809,000 rotors and 9000 looms (Mirza R. B., 2009). The table 2.1 below describes the contribution of textile industry in Pakistan's economy.

Anderson and van Wincoop (2004); and Feenstra, Markusen, and Rose (2001). aconsidered do not modify the basic relation between countries' masses and their trade flows. ${ }^{12}$ Given the relative small size of South Asian countries in the world markets such an assumption appears not to be problematic for the scenarios considered here. In summary, the general equilibrium approach offers the possibility of answering a richer set of questions but demands data not readily accessible for some of the countries we are interested in. ${ }^{13}$ Although the evaluation of the benefits and limitations of each methodology is beyond the scope of this paper it can be argued that they are complementary rather than substitutes. This paper uses a gravity equation approach and builds on Srinivasan (1994). In particular, it allows the response to trade barriers to differ by source of the goods; treats independently imports and exports of each country pair; and includes all seven members of SAFTA in the analysis. As Bandara and Yu (2003) and Gilbert, Scollay, and Bora (2001) show, welfare and trade volume do not necessarily follow a monotonic relationship and interpreting gravity equation results as describing desirability or welfare can be misleading. ${ }^{15}$ Nevertheless, by providing three different criteria-trade flows, trade balance and customs revenue-the paper provides information on the relative merits of alternative arrangements.

\section{Pak-India Trade Model}

\section{Aggregated Regions}

\section{GTAP Region}

1. Pakistan (PK) Pakistan

2. India (IND) India

3. Rest of South Asia

Sri Lanka

Bangladesh

Bhutan

Maldives

Nepal

4. Rest of the World (ROW)

all other Countries

SHAIKH (2013) 


\section{Pak-India Trade Project}

Table-1.Comparative Real GDP-Growth Rate (\%)

\begin{tabular}{|c|c|c|c|c|c|c|}
\hline Region/Country & 2009 & 2010 & 2011 & 2012 & 2013 & $2014(P)$ \\
\hline World GDP & -0.6 & 5.2 & 4.0 & 3.2 & 3.3 & 4.0 \\
\hline Euro Area & -4.4 & 2.0 & 1.4 & -0.6 & -0.3 & 1.1 \\
\hline United States & -3.1 & 2.4 & 1.8 & 2.2 & 1.9 & 3.0 \\
\hline Japan & -5.5 & 4.7 & -0.6 & 2.0 & 1.6 & 1.4 \\
\hline Germany & -5.1 & 4.0 & 3.1 & 0.9 & 0.6 & 1.5 \\
\hline Canada & -2.8 & 3.2 & 2.6 & 1.8 & 1.5 & 2.4 \\
\hline Developing Countries & 6.9 & 9.9 & 8.1 & 6.6 & 7.1 & 7.3 \\
\hline China & 9.2 & 10.4 & 9.3 & 7.8 & 8.0 & 8.2 \\
\hline Hong Kong SAR & -2.5 & 6.8 & 4.9 & 1.4 & 3.0 & 4.4 \\
\hline Korea & 0.3 & 6.3 & 3.6 & 2.0 & 2.8 & 3.9 \\
\hline Singapore & -0.8 & 14.8 & 5.2 & 1.3 & 2.0 & 5.1 \\
\hline Vietnam & 5.3 & 6.8 & 5.9 & 5.0 & 5.2 & 5.2 \\
\hline \multicolumn{7}{|c|}{ ASEAN } \\
\hline Indonesia & 4.6 & 6.2 & 6.5 & 6.2 & 6.3 & 6.4 \\
\hline Malaysia & -1.5 & 7.2 & 5.1 & 5.6 & 5.1 & 5.2 \\
\hline Thailand & -2.3 & 7.8 & 0.1 & 6.4 & 5.9 & 4.2 \\
\hline Philippines & 1.1 & 7.6 & 3.9 & 6.6 & 6.0 & 5.5 \\
\hline \multicolumn{7}{|c|}{ South Asia } \\
\hline India & 5.0 & 11.2 & 7.7 & 4.0 & 5.7 & 6.2 \\
\hline Bangladesh & 5.9 & 6.4 & 6.5 & 6.1 & 6.0 & 6.4 \\
\hline Sri Lanka & 3.5 & 8.0 & 8.2 & 6.4 & 6.3 & 6.7 \\
\hline Pakistan & 0.4 & 2.6 & 3.7 & 4.4 & 3.6 & 4.4 \\
\hline
\end{tabular}

\section{Source: Economic Survey of Pakistan-2012-13}

Table-2-Growth rate Percentage

\begin{tabular}{|c|c|c|c|c|c|c|c|}
\hline Sectors/Sub-Sectors & 2006-07 & $2007-08$ & 2008-09 & $2009-10$ & 2010-11 & 2011-12 & $2012-2013(P)$ \\
\hline 1. Agriculture & 3.4 & 1.8 & 3.5 & 0.2 & 2.0 & 3.5 & 3.3 \\
\hline Crops & 4.4 & -1.0 & 5.2 & -4.2 & 1.0 & 2.9 & 3.2 \\
\hline Important Crops & 6.5 & -4.1 & 8.4 & -3.7 & 1.5 & 7.4 & 2.3 \\
\hline Other Crops & 2.1 & 6.0 & 0.5 & -7.2 & 2.3 & -7.7 & 6.7 \\
\hline Cotton Ginning & -0.8 & . & 1.3 & 7.3 & -8.5 & 13.8 & -2.9 \\
\hline -Livestock & 2.8 & 3.6 & 2.2 & 3.8 & 3.4 & 3.9 & 3.7 \\
\hline -Forestry & 2.7 & 8.9 & 2.6 & -0.1 & 4.8 & 1.7 & 0.1 \\
\hline -Fishing & 0.4 & 8.5 & 2.6 & 1.4 & -15.2 & 3.8 & 0.7 \\
\hline Industrial Sector & 7.7 & 8.5 & -5.2 & 3.4 & 4.7 & 2.7 & 3.5 \\
\hline 2. Mining \& Quarrying & 7.3 & 3.2 & -2.5 & 2.8 & -4.4 & 4.6 & 7.6 \\
\hline 3. Manufacturing & 9.0 & 6.1 & -4.2 & 1.4 & 2.5 & 2.1 & 3.5 \\
\hline -Large Scale & 9.6 & 6.1 & -6 & 0.4 & 1.7 & 1.2 & 2.8 \\
\hline -Small Scale & 8.3 & 8.3 & 8.6 & 8.5 & 8.5 & 8.4 & 8.2 \\
\hline -Slaughtering & 3.2 & 3.3 & 3.8 & 3.2 & 3.7 & 3.6 & 3.5 \\
\hline Electricity Generation \& & -12.8 & 37.2 & -12.1 & 16.7 & 66.4 & 2.7 & -3.2 \\
\hline 4. Construction & 12.9 & 15.4 & -9.9 & 8.3 & -8.6 & 3.2 & 5.2 \\
\hline $\begin{array}{l}\text { Commodity } \\
\text { Sector }\end{array}$ & 5.5 & 5.1 & -0.9 & 1.8 & 3.3 & 3.1 & 3.4 \\
\hline Services Sector & 5.6 & 4.9 & 1.3 & 3.2 & 3.9 & 5.3 & 3.7 \\
\hline 7. Wholesale \& Retail Trade & 5.8 & 5.7 & -3.0 & 1.8 & 2.1 & 1.7 & 2.5 \\
\hline $\begin{array}{l}\text { 6.Transport, } \\
\text { and }\end{array}$ & 6.9 & 5.5 & 5.0 & 3.0 & 2.4 & 8.9 & 3.4 \\
\hline 8. Finance \& Insurance & 9.1 & 6.3 & -9.6 & -3.3 & -4.2 & 1.0 & 6.6 \\
\hline $\begin{array}{l}\text { Housing Services (Ownership } \\
\text { of }\end{array}$ & 4.0 & 4.0 & 4.0 & 4.0 & 4.0 & 4.0 & 4.0 \\
\hline General Government Services & 2.7 & 0.2 & 5.6 & 8.0 & 14.1 & 11.1 & 5.6 \\
\hline Other Private Services & 4.6 & 5.4 & 6.5 & 5.8 & 6.6 & 6.3 & 4.0 \\
\hline GDP (fc) & 5.5 & 5.0 & 0.4 & 2.6 & 3.7 & 4.4 & 3.6 \\
\hline
\end{tabular}




\subsection{Exporters' perception of barriers during export / Nature of problem faced by Pakistani exporters during export to the INDIA}

\section{Research Methodology}

Data were collected from 100 exporters by using simple random technique. Data were analyzed by using SPSS-20 version, A structural questionnaire was developed for the reliability and validity of the data

\section{One-sample t-test}

Table 2. One-sample t-test

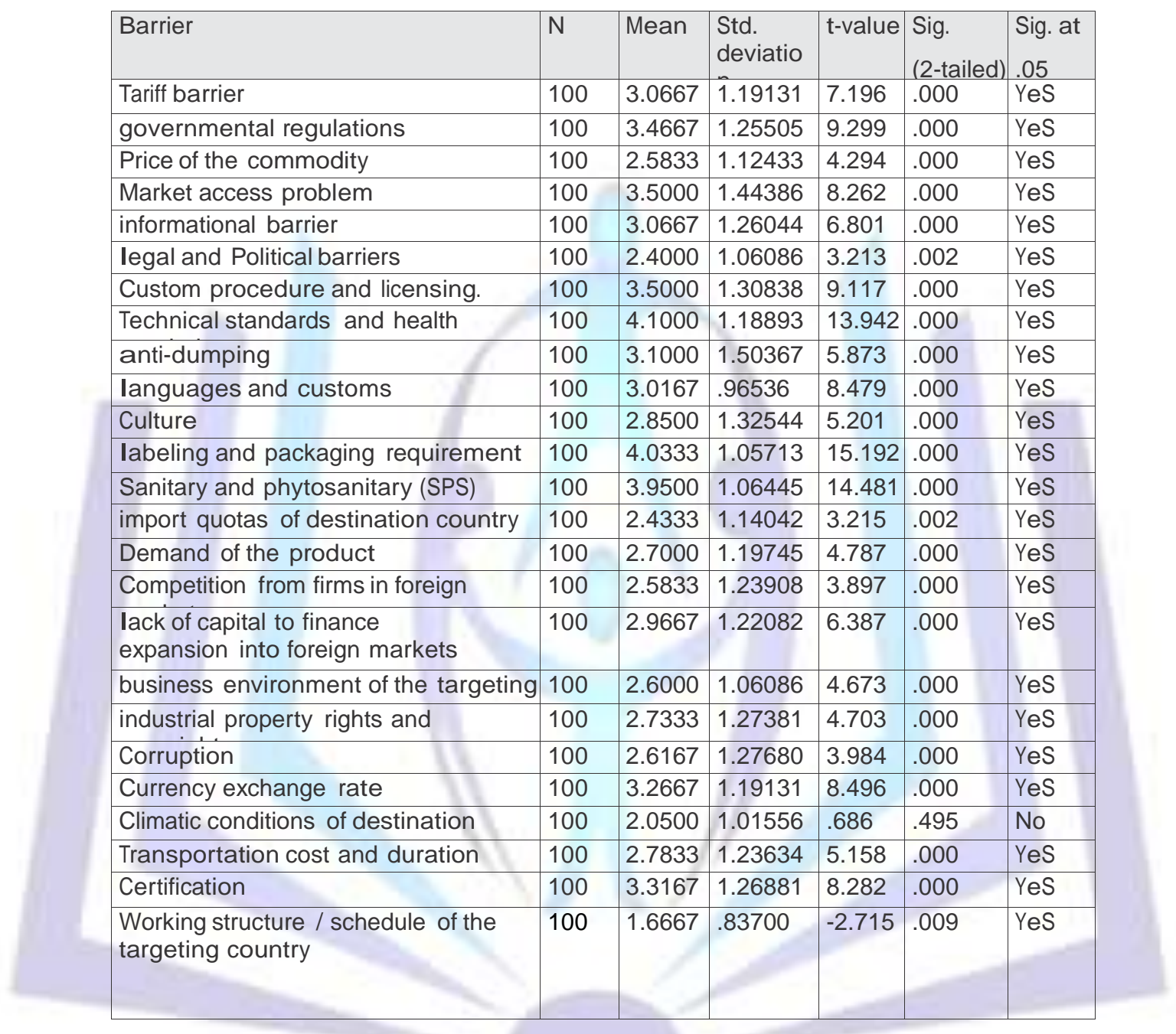

Table-7.1 shows that Pakistani exporters have significant feelings for all the barriers except the climatic conditions of the destination country, which are regarded by them as a Internal factor.

\subsection{Percentage analysis}

Percentage analysis has been done to check the strength of each significant barrier. These barriers are divided into two parts - common barriers to export and hidden barriers. Common barriers are those that exist due to governmental regulations and policies and which global organizations such as WTO find a solution, and they can solve through the agreements. Hidden barriers are those that exist naturally, and government bodies cannot really make solutions on them, but these hidden barriers can affect export negatively. 


\section{Common barrier}

Table 3. Percentage analysis of Pakistani exporters' perception of common barriers

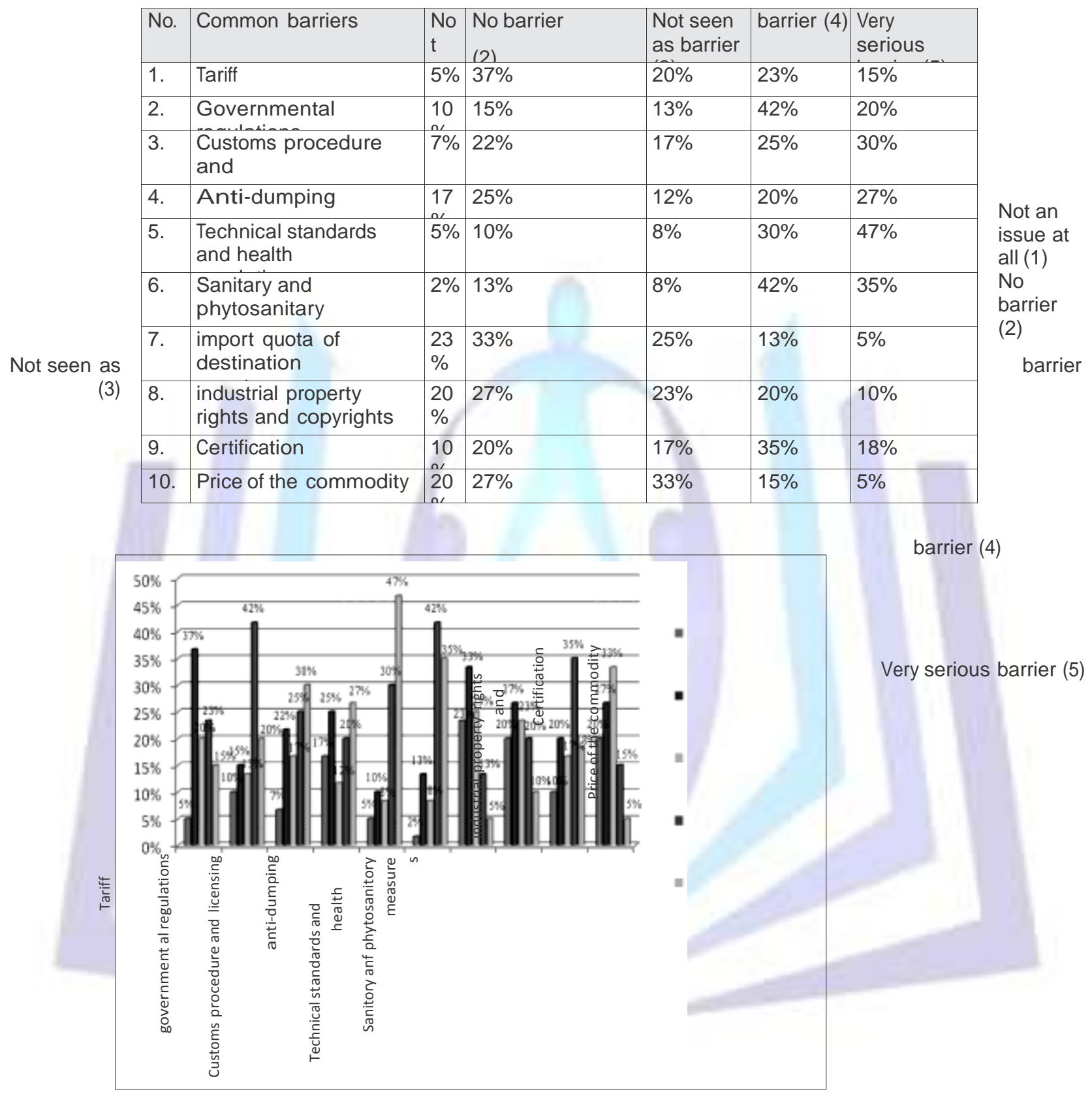

Fig. 2. Percentage analysis of Pakistani exporters' perception of common barriers 
Table 3 and Fig. 2 show that respondents regard governmental regulations, customs procedure and licensing, technical standards and health regulations, sanitary and phytosanitary measures and certification as the major barriers to export. The anti-dumping and tariff barrier are not the major barriers but tends to be the major ones. The tariff barrier may be low due to several rounds of GATT and WTo. The import quota of the destination country and the Price of the commodity are not regarded as barriers, either.

\section{Hidden barriers}

Table 4. Percentage analysis of Pakistani exporters' perception of hidden barriers

\begin{tabular}{|l|l|l|l|l|l|l|}
\hline No & Hidden barriers & $\begin{array}{l}\text { Not an } \\
\text { issue at all }\end{array}$ & $\begin{array}{l}\text { No barrier } \\
(2)\end{array}$ & $\begin{array}{l}\text { Not seen } \\
\text { as a barrier } \\
1 .\end{array}$ & $\begin{array}{l}\text { barrier } \\
(4)\end{array}$ & $\begin{array}{l}\text { Very serious barrier } \\
(5)\end{array}$ \\
\hline 1. & Market access problem & $13 \%$ & $17 \%$ & $10 \%$ & $27 \%$ & $28 \%$ \\
\hline 2. & informational barrier & $13 \%$ & $23 \%$ & $18 \%$ & $33 \%$ & $17 \%$ \\
\hline 3. & Iegal and political barriers & $25 \%$ & $27 \%$ & $33 \%$ & $13 \%$ & $2 \%$ \\
\hline 4. & Ianguages and customs & $5 \%$ & $23 \%$ & $43 \%$ & $22 \%$ & $7 \%$ \\
\hline 5. & Culture & $17 \%$ & $32 \%$ & $15 \%$ & $23 \%$ & $13 \%$ \\
\hline 6. & Demand of the product & $20 \%$ & $22 \%$ & $35 \%$ & $15 \%$ & $8 \%$ \\
\hline 7. & $\begin{array}{l}\text { Competition from the firms in } \\
\text { the foreign market }\end{array}$ & $25 \%$ & $23 \%$ & $27 \%$ & $18 \%$ & $7 \%$ \\
\hline 8. & $\begin{array}{l}\text { Iack of capital to finance } \\
\text { expansion into foreign }\end{array}$ & $15 \%$ & $18 \%$ & $33 \%$ & $22 \%$ & $12 \%$ \\
\hline 9. & $\begin{array}{l}\text { business environment of } \\
\text { the targeting country }\end{array}$ & $18 \%$ & $25 \%$ & $38 \%$ & $15 \%$ & $3 \%$ \\
\hline 10. & Corruption & $23 \%$ & $30 \%$ & $15 \%$ & $25 \%$ & $7 \%$ \\
\hline 11. & Currency exchange rate & $8 \%$ & $20 \%$ & $23 \%$ & $33 \%$ & $15 \%$ \\
\hline 13. & $\begin{array}{l}\text { Transportation cost and } \\
\text { d...natinn }\end{array}$ & $17 \%$ & $30 \%$ & $20 \%$ & $25 \%$ & $8 \%$ \\
\hline 14. & $\begin{array}{l}\text { Working structure / } \\
\text { schedule of the targeting }\end{array}$ & $55 \%$ & $25 \%$ & $18 \%$ & $2 \%$ & $0 \%$ \\
\hline 15. & $\begin{array}{l}\text { Iabeling and } \\
\text { packaging }\end{array}$ & $3 \%$ & $7 \%$ & $13 \%$ & $37 \%$ & $40 \%$ \\
\hline
\end{tabular}

Table 4 and Fig. 3 show that the respondents regard the market access problems and labeling and packaging as the major barriers to export. Although not the major barriers but cultural one, the currency exchange rate and informational barrier tend to be the major barriers to export. The Legal and Political barriers, Languages and Customs, demand of the product, working structure / schedule of the targeting country, business environment are not regarded as barriers to export.

When exporters were asked about the other barriers they face than the above- mentioned common and hidden barriers, most of the respondents said that coordination is another barrier they face mostly during export. 


\section{ISSN 2278-5612}

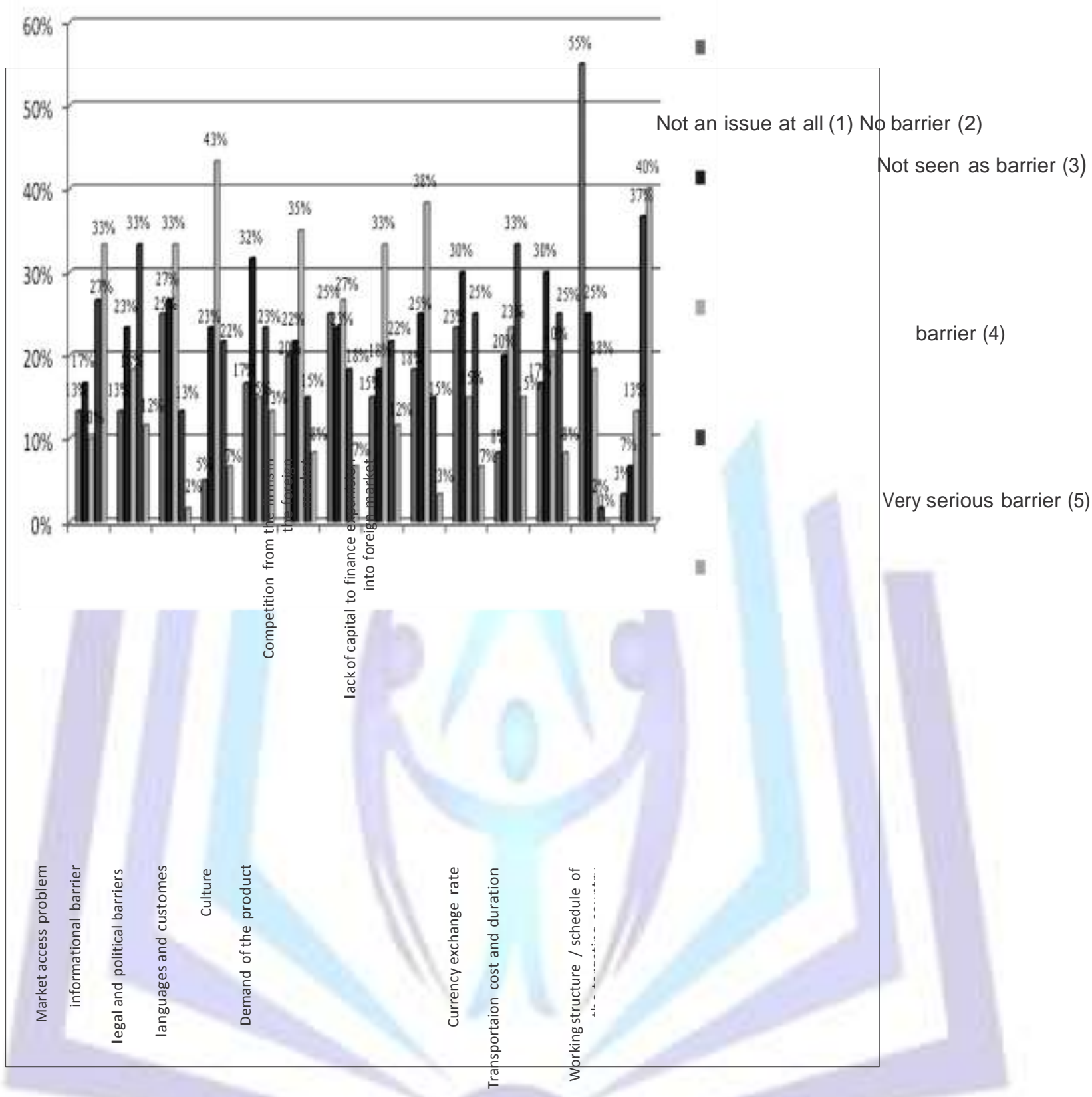

Fig 3. Percentage analysis of Pakistani exporters' perception of hidden barriers 2. Exporters' attitude after decreasing the strength of barriers

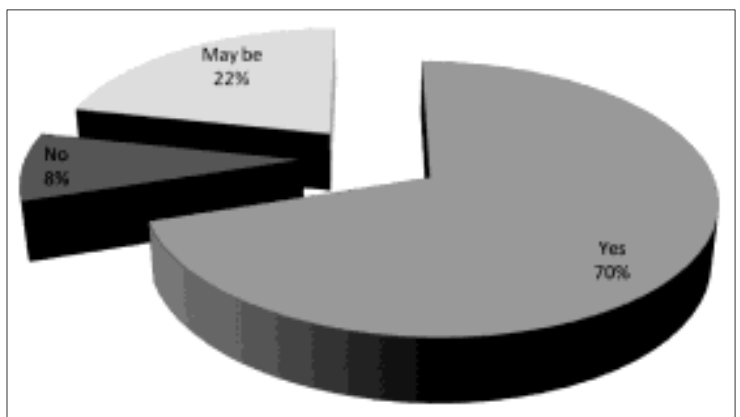

Fig. 4. Exporters' opinion on export after decreasing the strength of barriers 
Exporters have been asked if they are ready to export more to the INDIA after these barriers will be less, and $70 \%$ of the exporters said yes, $22 \%$ said maybe, and $8 \%$ said no. Thus, exporters are positive regarding export to the INDIA. India's export to the INDIA can be increased if these barriers get less or are removed.

\section{Conclusions}

This research focused on the issues and prospectus of Pak_India trade relations. According to results respondents regard governmental regulations, customs procedure and licensing, technical standards and health regulations, sanitary and phytosanitary measures and certification as the major barriers to export. The anti-dumping and tariff barrier are not the major barriers but tends to be the major ones. The tariff barrier may be low due to several rounds of GATT and WTo. It was further revealed that the respondents regard the market access problems and labeling and packaging as the major barriers to export. Although not the major barriers but cultural one, the currency exchange rate and informational barrier tend to be the major barriers to export

\section{References}

1. Ahmed, S., S. Kelegama, and E. Ghani (2010). Promoting Economic Cooperation in South Asia: Beyond SAFTA. Sage Publications, New Delhi.

2. Bandara, J. S. and Yu, W. (2003). "How Desirable is the South Asian Free Trade Area? A Quantitative Economic Assessment." In Greenaway, DS. (ed.) World Economy: Global Trade Policy 2003, Oxford, U.K.: Blackwell Publishing

3. Baysan, T., Panagariya, A and Pitigala, N. (2006). "Preferential Trading In South Asia", World Bank Policy Research Working Paper 3813, January 2006

4. Bhagwati, J., and Panagariya, A. (1996). "The Theory of Preferential Trade Agreements: Historical Evolution and Current Trends." American Economic Review. 86(2): 82 - 87.

5. Coulibaly, S. (2004). "On the Assessment of Trade Creation and Trade Diversion Effects of Developing RTAs," Paper Presented at the Annual Meeting 2005 of the Swiss Society of Economics and Statistics on Resource Economics, Technology, and Sustainable Development. (available at http://www.wif.ethz.ch/resec/sgvs/078.pdf)

5. CUTS, (2012), "Cost of Economic Non- Cooperation to Consumers in South Asia", Working Paper, Consumer Utility Trust Society, Jaipur, India.

6. CUTS, (1996). "Cost of Non - Cooperation to Consumers in the SAARC Countries: An Illustrative Study", Working Paper, Consumer Utility Trust Society, Jaipur, India.

7. Das, S. and Pohit, S. (2006), "Quantifying the Transport, Regulatory and Other Costs of Indian Overland Exports to Bangladesh," The World Economy, Vol. 29, No. 9, 1227- 1242.

8. De, P. and Raihan, S. (2011), "Unlocking India-Bangladesh Trade Potential: Emerging Issues and the Way Forward", paper prepared for the World Bank.

9. DeRosa, D. A. and Govindan, K. (1995). "Agriculture, Trade, and Regionalism in South Asia." Food, Agriculture, and the Environment Discussion Paper 7, Washington, D.C.: International Food Policy Research Institute.

10. Dimaranan, B.V. and R.A. McDougall. Global Trade, Assistance, and Production: The GTAP 5 Data Base, Center for Global Trade Analysis, Purdue University. 2002.

11. Feridhanusetyawan, T. 2005. Preferential Trade Agreements in the Asia- Pacific Region. International Monetary Fund Working Paper 05149. Washington, DC: International Monetary Fund.

12. Ju, Jiandong and Kala Krishna. (1998). Firm Behavior and Market Access in a Free Trade Area with Rules of Origin. NBER working Paper, No. 6857.

13. Panagariya, A. (1994). East Asia and the New Regionalism. World Economy, 17:6, 817-39.

14. Panagariya, A. (1995). Rethinking the New Regionalism', Paper Presented at the UNDP World Bank Trade Expansion Conference, January, World Bank, Washington DC.

15. Panagariya, A. (2000). Preferential Trade Liberalization: The Traditional Theory and New Developments. Journal of Economic Literature, 38, June 287-331.

16. Purcell, Garry. (2004a). Analyzing the Economic Welfare Consequences of A Fare Trade Agreement: Partial Equilibrium Methods for Industry Level Studies, Manuscript Presented at World bank Dhaka Office.

17. Purcell, Garry. (2004b). An India-Bangladesh Free Trade Agreement? Some Potential Economic Costs and benefits, presented during the workshop held at World Bank, Islamabad Office.

18. Summers, L. (1991). Regionalism and the World Trading Systems, Federal Reserve Bank of Kansas City, Polic 


\section{ISSN 2278-5612}

19. GEP, (1998). "The Report of the SAARC Group of Eminent Persons", SAARC Secretariat, Kathmandu. y Implementation of Trade and currency zones 